\title{
DOI: 10.7596/taksad.v9i3.2702
}

Citation: Vasko, R., Korolyova, A. Pakholok, Z., \& Korolyov, I. (2020). Logic and Semiotic Passportization of Numbers in Different Cultures. Journal of History Culture and Art Research, 9(3), 277-287. doi:http://dx.doi.org/10.7596/taksad.v9i3.2702

\section{Logic and Semiotic Passportization of Numbers in Different Cultures}

\author{
Roman Vasko ${ }^{1}$, Alla Korolyova², Zinaida Pakholok ${ }^{3}$, Igor Korolyov ${ }^{4}$
}

\begin{abstract}
This article is a continuation of the discussion of a new idea about the need to compile a culturological passport of each number and its symbolic sacralization in different cultures, which was proposed for an interdisciplinary study in one of his works by the co-author R. Vasko "Semiotic and Culturological Passportization of Numeric Phraseosymbols". The team of the article authors makes convincing arguments that the symbolic parameter should be the initial criterion for systematization of numbers in such a passport-calendar (a kind of database). The source of the symbolism of the number is, first of all, the mythology of different peoples of the world, which helps to reveal through quantitative characteristics the internal properties and qualities of various events. Taking into account the mythological and semiotic sacred parameter of the passportization data of modern numbers, it is proposed to consider numbers as a configuration of the symbolism of previous and subsequent signs, which undergo further transformation and, thus, receive a new sacred component in their mythopoetic meaning, characteristic of each national culture. A preliminary conclusion is made that the process of the number symbolization from one to thirteen in the mythopoetic traditions of different cultures reflects both the paradigmatics of the numerical series (i.e., its structure and properties of its members) and syntagmatic (i.e., functioning of numbers in mythopoetic and folklore texts).
\end{abstract}

Keywords: Passportization of numbers, culturological passport, symbolism of numbers, sacred parameter, semiotics of language, culturological semiotics.

\footnotetext{
${ }^{1}$ Doctor habil. in Philology, Professor, Rector, Kyiv National Linguistic University, Kyiv, Ukraine, 03680. E-mail: dnister@ukr.net

${ }^{2}$ Doctor habil. in Philology, Professor, Vice-Rector for Research, Kyiv National Linguistic University, Kyiv, Ukraine, 03680. E-mail: allakor2008@gmail.com

3 Doctor habil. in Philology, Professor, Open International University “Ukraine”, Lutsk Human Development Institute of the University "Ukraine", Department of Information Activities and Tourism, Lutsk, Ukraine, 43000. E-mail: paholok@ukr.net

${ }^{4}$ Doctor habil. in Philology, Associate Professor, Senior Researcher, Taras Shevchenko National University of Kyiv, Institute of Philology, Scientific and Research Department, Kyiv, Ukraine, 01601. E-mail: korolyovigor@gmail.com
} 


\section{Introduction}

In modern cultural studies, the issue of the need for the passportization of cultural symbols and those that have the status of cultural codes is increasingly being discussed. The conceptual vector of this discussion was set in one of the publications of the co-author of this article, R. Vasko, "Semiotic and Culturological Passportization of Numeric Phraseosymbols", where the scholar argues that the Pythagorean "principle of the world ordering, through the prizm of which it is necessary to consider the process of their sense-making and further interpretation as signs of national culture" (Vasko 2019).

Considering the fact that the number (counting) belongs, according to Yu. Lotman, to the oldest archetypal layers of the semiosphere (Lotman, 2001: 26-27), there is every reason to assume that the numbers themselves and the units that have numerical components in their composition are the sense-forming fragments of the conceptosphere of each nation's culture. A number can also constitute a holistic discursive practice or its component, and thus, is a sign of communicative consciousness (Korolyov, 2020).

To confirm this hypothesis, we quote the words of $O$. Spengler, who believed that "a number always expresses a certain worldview of the people, which is obvious and does not require a logical justification for a particular culture. Therefore, each culture generated its own mathematics" (Spengler, 1993: 201-247). Being a component of the model of the world, the number has become, above all, that symbolic sign, the compiled passport of which will make it possible to determine the specifics of associative-figurative thinking and world perception of a certain ethnic group's representatives.

Based on this formulation of the research problem, this topic is relevant and promising for further study of such a new concept as a culturological passport / portrait of any object of culturological semiotics.

The aim of the article is to systematize the logical-semiotic passportization data of numbers from one to thirteen in different cultures, taking into account their mythological-sacral code and nationalcultural symbolism.

\section{Sources of numbers in different cultures as the initial parameter of their passportization}

As known, the number is one of the most important concepts of mathematics, which originated in the primitive society in connection with the need for counting and measuring in the practical activities of man. Sources of the Indo-European proto-language and "the facts of the use of quantitative totals by a person in the Late Paleolithic period found on a large territory of Europe and Asia indicate the same ways of knowing reality and developing his thinking" (Taranets, 1999: 19). In archaic traditions, numbers "have become an image of the world, as well as a means to overcome destructive chaotic tendencies in the cyclic pattern of the world development" (Toporov, 1998: 629).

We find a primary conceptual representation of the number in mythology, where it denoted a class of signs oriented to a qualitative-quantitative assessment: "the comparison of things, phenomena, events with numbers passed from the Babylonians to the Greeks, from the Greeks to the peoples of India and further to the Arabs, and then dominated in the Middle Ages and has survived to the present time" (Borodin, 1975: 104). According to the ancient mythological and poetic traditions, numbers had and have sacred meaning, symbolizing harmony and order and embodying magical power (Makovsky, 1996: 388). Remaining the most important component of the conceptual system of man, the number is considered a constant of the material and spiritual culture of society.

Later, already in the genres of folklore, the number becomes one of the main objects of the cosmological model of the world. So, for example, in the riddle describing the year cyclicity: "There is 
a pillar to heaven, there are 12 nests on it, 4 eggs in each nest, 7 embryos in each egg" (Toporov, 1998: $631)$, is precisely the numbers that serve as symbolic signs.

\section{Mythological and semiotic sacred parameter of the modern numbers passportization data}

The scientific idea of the categorical status of the number is most closely associated with the formation of the category of quantity (definite and indefinite), characteristic of different lexical and grammatical classes of words such as "hundred", "single", "many", etc." (Vinogradov, 1990: 583), and relics of its mythological and semiotic nature are reflected in binary characteristics and, above all, in the contrast of singularity and plurality (Vinogradov, 1990: 584).

In the proposed system of certification of numbers, their series starts with the number one, since it "denotes the center from which the" left - right", "top - bottom "are opposed, and the center of the Universe is considered to be the Sun - the only one star in the series" (Voitovych, 2002: 582). At the same time, we note that primary ideas about the whole, integrity, unity associated with the number 1 are practically not found in the most ancient texts, which "can be explained by the use of this number by images of perfect integrity such as the God or the Cosmos" (Toporov, 1998: 630).

According to the Pythagoreans, the figure "one" is the mother of all numbers. It equipolently combines binary semiotic oppositions such as the even - the odd, male - female, and therefore is considered the basis of the universe. The etymology of the word oдuн "one" goes back to the common Slavic root eдuнъ, which is formed by adding up the stems of $\boldsymbol{e d - a n d - i n}(16,304)$. In modern Slavic languages, it has the form jedin in Bulgarian and jeden in Polish, in the Baltic languages vienas in Lithuanian and viēns in Latvian, which etymologically ascend from Proto-Balto-Slavic *einas (with ey> ie metathesis; from a Proto-Indo-European *éyno-, éynos, from * éy, * óy ("he, it") (non-Baltic cognates derive from *óy; compare Proto-Indo-European *óynos ("one") with a suffix *-no, which originally had an adjectival meaning (Karulis, 1992).

In Russian, the word один "one" is polysemic, as it has nine meanings and "belongs to the lexico-grammatical class of numerals; in the meaning of the adjective it means: "without others, separately from others, alone; none other or nothing else; the only; the same, identical; the same; cohesive; indivisible; single", and in combination with "the other" it is used for contradistinction of persons, objects or phenomena based on any grounds, indicating their difference or change; with the preposition "from" it is used to highlight a single person, object, phenomenon, etc. or a group of persons, homogeneous objects from any category, environment, series; in combination with "the other" it is used for enlistment, contradistinction, etc. of a number of persons, objects, phenomena; in the meaning of an indefinite pronoun: any, some" (Dictionary of the Russian Language, 1982: 592).

Doubling the word root led to the formation of reduplications of один-единственный - the one and only-один-одинехонек and один-одинешенек - 'the only one', and with a complementary color of amplification один-разъединственный - alone and no other - 'one and only'; одна-одна one and sole - "completely alone". One of the authors of this article considers in more detail about the ontology of the category of repetition as a psychophysiological factor (Pakholok, 2019).

In Ukrainian the lexeme one is also polysemic and has ten meanings, nine of which are similar to those in Russian, the tenth is the use of the word alone in the meaning of the adverb "all the time, constantly, continuously" (Large Explanatory Dictionary, 2001: 659). The reduplications formed with the numeral one in Ukrainian, один-єдиний - "one and alone" is the emphasis on quantity with the value of exclusivity; один-однісінькій - "quite alone" - is the emphasis on quantity with the value of diminutiveness; сам-один - "self-alone, without anyone; without kith and kin, without friends; without anyone's participation, help, on his / her own; all alone, independently" (Dictionary of the Ukrainian Language, 1978: 24). In modern Ukrainian mass media, the phraseologism один плюс один 
"one plus one" lays emphasis upon the significance of the constituent components, one could say "two", which, in terms of quantity, is one and the same. This expression has acquired great relevance in Ukraine, being the name of the popular TV channel " $1+1$ ", the slogan of which is the phrase "You are not alone, one plus one".

Regarding the ordinal number with the value "one", the researcher Yang Shizhan writes: "the analysis of the expression "for the first time "in ancient sacred texts is associated with the creation of the world in its entirety and continuity, and this is the only denotation of this expression, in contrast to its understanding in modern languages and cultures (Shichzhan, 2001: 70).

Two. It is known that during the Late Paleolithic period, doubling of different aggregates occurred, which provided a means "to allow the existence of an already fixed idea of duality" (Taranets, 1999: 19) or binarity, that gradually replaced the concept of equipollence and became an integral part of the daily life of a primitive man. According to V. Taranets, "the logical opposition of the whole / part could find implementation in the form of the simplest dual formations of the existing roots. This is a reduplication of the same root or composition of different roots that form a more complex conceptual image or reflect the semantic division of the primary (equipollent - clarification by A. Korolyova) root image" (Taranets, 1999: 59).

Binarity has become a system of contradistinction (two meanings of the gender category; heaven and earth, day and night, real world and afterworld, the two sides of the hunt, war, etc.). Paired relationship was recognized as disjointedness and was reflected in the consciousness of an ancient man in paired objects: arms, legs, eyes, the right or the left sides of a man or animal, moon or sun, east and west, north and south. Thus, the number two acts as a symbol of opposition, separation and communication, on the one hand, and as a symbol of correspondence or homology of members, on the other.

The concept of "even-odd" was actively discussed by the Pythagoreans. In Metaphysics, Aristotle wrote:

they took the number as the beginning: both as the matter for the existing, and as an expression of its states and properties, the even and the odd were considered the elements of the number, of which the latter is the ultimate and the former is the illimitable; the one whole consists of both of them (namely: it is even and odd). A number comes from a single, and the whole sky is a number. Other Pythagoreans claimed that there are ten principles arranged in pairs: the ultimate and the unlimited, odd and even, single and plural, right and left, male and female, stationary and dynamic, straight and curved, light and dark, good and bad, square and oblong (Aristotle, 1975: 76).

The Pythagorean teaching of the binary classification of all things is reflected in the Old Slavic faith in the even and the odd ("God loves the odd", "The odd is happy"). The etymology of the common Slavic word "dva - two" is of Indo-European origin (Shanskiy, Ivanov, Shanskaya, 1975: 120), which is manifested not only in the Slavic and Baltic languages: in Bulgarian - $\partial \boldsymbol{\varepsilon a}$ " two", in Polish - $\boldsymbol{d} w \boldsymbol{w a}$ "two"; in Lithuanian - du "two", in Latvian - divi "two"; but also in German - zwei "two" English - two (where the phonemic correspondence of Indo-European /d/ to Germanic/t/ in the root is observed).

In Russian, the opposition "even-odd" was fixed in the expression "Черma c двa!", which has a pejorative colour and means "Nothing of the kind! Of course not!,No way!". Here, the choice of the number is not accidental, since $\partial \boldsymbol{\delta} \boldsymbol{\theta a}$ "two" is an even, unclean number. In general, the recognition of the real, lucid and otherworldly, dark world has become the basis for many superstitions: double or reduplicated objects could bring misfortune and even death (Voitovych, 2002: 583).

Three. As for number three, the Pythagoreans considered it the first real number, because it has a beginning, middle, and end. The number three is an image of absolute perfection, superiority, 
reflecting the main numerical characteristics of the Universe associated with its vertical spatial division: heaven, earth, hell, underworld, the nether world (Ivanov \& Toporov, 1965: 81).

It is the main constant of the mythopoetic Macrocosm (cf. derivatives from the English number three (in Slavic languages: $\boldsymbol{m p u}$ - in Bulgarian, trzy - in Polish; in the Baltic languages: trys - in Lithuanian, trīs - in Latvian), in particular, the form of English tree - "world tree" as a symbol of the ancient German model of the world) and social organization (including the norms of standard behavior).

Compare, for instance, three spheres of the Universe, the three highest values, the divine trinities (three coeternal consubstantial persons or hypostases, three-headed deities such as the Slavic Triglav, the ancient Indian Trimūrti - "three faces"; compare also the names of mythological characters with the internal form "three": Sanskrit Trita - lit. "the Third" - a minor deiety of Rigveda"; Avestan Oraētaona, Pehlevi Frēdōn, Persian فريدون, Tadjik Феридун, Old Greek Tpit

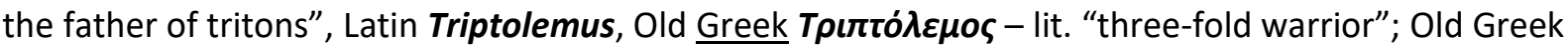

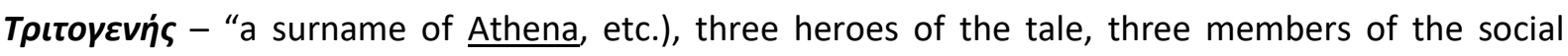
structure and three social functions, the ternary principle of composition in the works of art" (Toporov, 1998: 630). The number three symbolizes dynamic integrity and can serve as an ideal model of any dynamic process.

The Gold Trident is a symbol of the god Troyan, who holds three Suns (Voitovych, 2002: 545). The trident - "the family coat of arms of the Kiev princes - Is already found on coins from the era of Prince Svyatoslav and his son Vladimir, the only difference being in that Svyatoslav has two prongs "teeth of the weapon" on it, and Vladimir has three" (Voitovych, 2002: 584).

Three means "the whole world" towards heaven, "the totality of the kingdoms of the upper middle - lower; the worlds Nav - Java - Right; heaven - earth - water; morning - day - night; father mother - child; childhood - youth - maturity - old age. The Trinity, according to ancient beliefs, was made up of Java - the earthly world, Nav - the invisible, spiritual world, and Prav - the world of the laws of material and spiritual being, existence. There was also a doctrine of the Trinity, i. e. (three

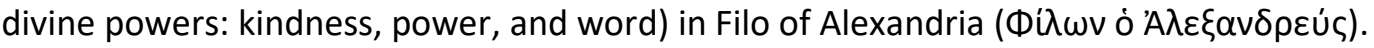

The number three became the symbol of faith in the Christian religion, where God appears in three hypostases: God the Father, God the Son, God the Holy Spirit. The Trinity is one of the most important holidays of the Orthodox church calendar, which is celebrated on the 50th day after Easter.

There are its own laws in the magic and folklore of the number three. For instance, Russian, $\mathbf{3 a}$ тридевять земель, в тридесятом царстве "beyond the thrice-nine lands in the thrice-tenth kingdom"; три богатыря "three strong heroes"; трехкратное испытание героя "triple probation of the hero"; три раза кланяются "bow three times"; три раза целуются при встрече и разлуке "kiss three times at a meeting and separation"; три дороги "three roads"; три соблазна "three temptations"; три подарка "three gifts"; mри месяца "three months"; mри корысти "three self-interests", etc. (Voitovych, 2002: 583-584).

The proverb says that "One son is not a son, two sons are a half-son, and three sons are a son." "The peasant has three sons: / The smart eldest was a muscleman, / The middle son was that way and every way, / The younger was quite a fool" (Ershov, 1987: 3). However, the youngest, beloved Ivan the Fool, was always probated thrice by the fate.

Three kingdoms (copper, silver, and gold) are described in folklore. In fairy tales, according to a famous folklore researcher V. Propp, they can be represented as overworld, earth, and underworld. Three kingdoms "are not under each other, but one in front of the other, commonly all three are 
underground" (Propp, 1946: 265). And it is no coincidence that the oral folk art repetitions were multiples of three (three, six, nine) and became a traditional narrative.

The number three was the border, which the score did not go beyond for a long time. It once meant "a lot", and "a lot" meant the same as "strongly", "much", i.e. intensity was determined through "the great many" (Propp, 1963: 70-71). Later, numerical complexes and related repetitions typical of oral folk art were transferred to fiction.

The number four symbolizes static integrity, an ideally stable structure, therefore it is used in creation myths and orientation in the Universe: four corners of the earth, four seasons. In cosmogonic myths, the tetramerous model appears as implemented in the horizontal plane: the North, the South, the West, the East, four main directions, four gods, four seasons: spring, summer, autumn, winter. Four Gospels are written by four evangelical writers.

The symbolic meaning of the number four is associated with the symbolism of the square and the cross. Back in prehistoric times, the number four was used to denote sustainability. In the biblical tradition, the number four conveys the idea of universality (in the Slavic and Baltic languages, the number four has the form of a chetiri in Bulgarian, cztery in Polish, keturi in Lithuanian, četri in Latvian): the four colors of the apocalyptic horse riders correspond to the four phases of the day and the four main points of the space: the East, the West, the South, the North.

The following numbers, including the number five, one way or another include the mythological and semiotic passportization data of previous numbers as signs. The number five is the sum of an even number two and an odd number three, which corresponds to the difference between the masculine and feminine principle, i.e. Yang and Yin and therefore the amount sum of these numbers, which is five, is a symbol of marriage.

The number five is a symbol of man; it is graphically represented by a figure of man whose head, arms, and legs astride form a five-pointed star (pentagram). In addition to this association with the human microcosm (as well as with the hand), the number five was an important symbol of the Universe in Chinese, Japanese, Celtic, and other traditions (the four corners of the earth plus the Center).

According to the doctrine of Pythagorean mysticism, the number five, like seven, was sacred, combining a three (sign of heaven) and a two (sign of earth), and was the number on which the laws of nature and art are based (Dictionary of Symbols). In Christian iconography, five is the number of Christ's wounds. In the Islamic tradition, five is a beneficial and protective symbol. The fundamental aspects of worship in Islam are encompassed within five pillars: Testimony of Faith (Shahadah), Prayer (Salat), Charity (Zakat), Fasting (Sawm), Pilgrimage (Hajj). In Judaism, the number five is a symbol of power; in alchemy - the sign of the fifth element, the quintessence.

In the Slavic and Baltic languages, the number five has genetically related derivative forms: in Ukrainian - ח'яmь, in Bulgarian - nem, in Polish - pięć, in Lithuanian - penki, in Latvian - pieci.

The number six symbolizes ambivalence and balance. The world was created in six days, God created the world by six words. Ancient wise men considered six as a perfect number, since $1 \times 2 \times 3$ and $1+2+3$ give one and the same six. Its graphic expression is a hexagram (hexagon), it contains the union of two triangles (fire and water) and denotes human soul: one with its top up (male principle, fire, sky), the other with its top down (female principle, water, earth). This figure, known as the Star of David, symbolized the union of two Semitic peoples - the state of Israel and Judea. The Chinese prophetic Book of Changes is also based on six broken continuous lines, the combination of which makes up a system of 64 linear hexagrams. 
In the Pythagorean system, six is a sign of good luck or happiness; it is a cube with six facets symbolizing sustainability and truth (Dictionary of Symbols). According to representatives of the Pythagorean school, the number six is an ideal number, it is divided by two as well as three. It is known that in the middle of the twentieth century there were people who knew how to count only to seven. Representatives of the Bacairis Indian tribe living in the jungles of Brazil "operate two numbers: tokale - one, ahage - two. To get three, they add ahage and tokale. Five looks like a sequence of ahageahage-tokale. The number six is pronounced as ahage-ahage-agache" (Native Americans' Arithmetic, 1965: 97). Anything more than six means a lot.

In Bulgarian, the number six is written as wecm, in Polish - sześć, in Lithuanian - šeši, in Latvian - seši.

In the holy books of the Christian religion, the number seven is quite symbolic, for instance, at the end of the New Testament in "The Book of "Revelation", where the author sees God sitting on the throne and holding a scroll in his right hand, which is sealed by seven seals. When the seals are removed from the scroll, different woes happen. When the seventh seal was removed, seven angels appear and they were given seven trumpets. When the seventh angel sounded his trumpet, new seven angels come on stage with seven golden bowls of the wrath of the Lord, etc.

Rome has long been called "The city on seven hills", later this name was also transferred to other large cities (Beirut, Babylon, Kyiv, etc.). It was believed that the Tower of Babel had seven floors, the Buddha was sitting under a tree with seven fruits. Mythology, legends, traditions of the peoples of Siberia, and the Far East are also fraught with magic sevens. The number seven is used in them, first of all, to characterize the Universe as a whole, space processes in time and space. Timeline indicators range from seven days to seven generations.

There is a hypothesis that the number seven is associated with the cult of the Moon. It was convenient for people in ancient times to count the time on the lunar calendar; the month was divided into two equal parts, fourteen days each, which corresponded to the growth and decrease of the Month, the next was the division of each part into two seven-day parts, i.e. prototypes of modern weeks.

The explanation of seven as a magic number also dates back to the Pythagoreans, astrologers and alchemists and is the world absolute number of all symbols, because it consists of three and four. It is considered as a synonym of completeness, perfection, the highest degree of ascent to knowledge. It has magical powers, because it manifests itself everywhere where there is a secret: this is the number of mortal sins, etc. (Borodin, 1975: 117-118).

Seven metals in ancient times were represented by astrological signs: the Sun - gold, Month silver, Jupiter - tin, Venus - copper, Saturn - lead, Mercury - mercury, Mars - iron.

Among different nations, the number seven played a significant role in life: the French took an oath, backing it up with the words "tight as seven", the Greeks spoke of seven wonders of the world, such as the Pyramids in Egypt, the Hanging Gardens of Babylon, the Temple of Artemis at Ephesus, the statue of Zeus at Olympia, the Mausoleum at Halicarnassus, the statue of the Greek sun-god Helios, erected in the city of Rhodes (Colossus of Rhodes), the Lighthouse of Alexandria. In addition, the Greeks had a cult of seven elders (wise men) and seven liberal arts that were part of the scholastic education system. The subjects in the medieval school included two cycles: the propaedeutic, the socalled trivium, and the final one, the quadrivium. The trivium consisted of grammar, rhetoric, and dialectics, whereas the quadrivium consisted of music, arithmetic, geometry, and astronomy. Starting from the Renaissance, this system of the study subjects began to be replaced by classical education. 
The ancient world left us the expression "be in the seventh heaven" in the figurative meaning of "be on top of the world, be overjoyed". The seven heavens are also discussed in the holy book of Muslims - the Qur'an (see more Vasko, 2019).

The heroine of fairy tales the Seven-year-old girl embodies the living experience and wisdom of the people. "A child under seven is an innocent soul, by it, old people say, angels stand..." (Voitovych, 2002: 585). There is also a legend in which a grandmother brought a buckwheat (Saracen corn) seed to Russia and buried it in the ground; the seed sprouted and spawned a stem with 77 grains on it; but tempestuous winds blew and spread these grains to 77 fields, since then buckwheat has begun to grow everywhere.

Eight. The Pythagoreans considered the number eight to be a symbol of death, perhaps because the reign of many ancient Greek kings was limited to eight years. The eight-year cycle (in every eightyear period the full moon coincides with the longest and shortest day of the year) is determined by the astronomical order, which was the basis for the compilation of ancient Greek calendars.

The symbolism of the expression "seven wonders of the world" is, of course, figurative, because it does not cover all the architectural wonders of Ancient Greece and Egypt. It is clear that there were significantly more of them. However, the intention to name the eighth miracle remained only an attempt. The expression "the eighth wonder of the world" is used when we want to magnify something, to bring it above the level of something ordinary.

The significance of this number is reflected in Indian sources: "eight parts of the body, eight noble sciences, eight mental moods, eight illustrious games, eight goddesses-defenders, eight incarnations of Shiva, eight degrees of yoga, eight sections of medicine. There are eight deities, i. e. guardians of the sides of the universe in Indian mythology" (Voitovych, 2002: 585).

In Bulgarian the number eight is written as ocem, in Polish - osiem, in Lithuanian - aštuoni, in Latvian - astoni.

Nine consists of three triples, denoting power, the highest spiritual power. "For nine months, the mother in her bosom carries the child; God Perun takes special care of that family, which has nine children. Nine days and nights are necessary for comprehending human wisdom" (Voitovych, 2002: 586). The Slavs commemorate one's passing on the ninth day after death.

The Pythagoreans called the nine the "limit of all numbers". But in this number, there is still a certain incompleteness and insufficiency. Therefore, the eight in their interpretation had the status of "insufficiency", but the ten, on the contrary, acquired the opposite meaning and became the number of "absolute completeness" (Chelyshev, 2017: 213).

The number nine plays an important role in numerical mysticism, especially among those peoples who use the lunar calendar, where the third part of the month was equal to nine days. It was considered as a symbol of wisdom, fate, knowledge, training, strength. It is in direct connection and dependent on the number three. The name of I. Aivazovsky's painting "The Ninth Wave" reflects popular beliefs about the forces of nature, in which the ninth is the most powerful.

Sometimes it is conceived as the number three, only in a strengthened form (three times three). "The Tale of the Fool Tereshka" reflects numerical symbolism: when dying, the father bequeathed to his sons to come to his grave for nine days. The eldest sons did not keep their word, and the smallest - "the fool" recited prayers for everyone. The father gave him three sticks, from which the sons got as gifts three horses: black, bay, and gold. On a golden horse, Tereshko galloped to the palace of the princess and became king. 
The number nine in Bulgarian is девеm, in Polish - dziewięć, in Lithuanian - devyni, and in Latvian - devini.

Ten is the sacred number of the Universe, because it contains all the other numbers. In ancient times, among many peoples the number ten was a new counting unit, so it was a symbol of harmony and completeness.

Ten was considered as an absolute number, as a symbol of integrity, completeness and perfection. Among the Pythagoreans, the ten became the universal number of Cosmos, which was formed from the sum of the first four numbers: $1+2+3+4=10$, hence the decimal number system got its theoretical justification, and the concept of "ten" began to symbolize perfection itself for centuries (Chelyshev, 2017: 214).

Languages of the Indo-European system in ancient times had a well-developed number system, based counting by tens.

Of great interest is the formation of numerals in the Papuan languages, in which "they are associated with the designation of parts of the body. The first four counting words are almost always the names of fingers. Here the interesting differences begin. In Kewa, for example, four fingers (except the thumb) are declared "hands", but the thumb is counted separately. For example, 10 is.

two hands and two thumbs. But in the Telefol language it is generally irrelevant whether we have reached the whole hand or not; there the score goes like this: 1) the little finger of the left hand; 2) ring finger; 3) middle finger; 4) index finger; 5) the thumb of the left hand; 6) the wrist of the left hand; 7) the forearm of the left hand; 8) left elbow; 9) biceps of the left hand; 10) the left shoulder; 11) the left side of the neck; 12) the left ear; 13) the left eye; 14) nose; 15) the other eye; 16) the other ear ... and so on until 27 - to the little finger of the right hand. The number 27 acts as the basis of the numerical system: the next class (hundreds equivalents) is $27^{\prime} 2$ and so on up to $27^{\prime} 14$. Beyond this number, called deeng mitkal, a Papuan Telefol cannot imagine: it is a synonym for the expression "very much". The same principle, i.e. "from little finger to little finger", is applied in other languages, only the names of different parts of the body and in different quantities are used. There are 37 of them in the Kubuntu language. In addition, the transition to the other side of the body is carried out at different points: in Telefol - on the nose, in Kewa - on the bridge of the nose, in the Mandobo language - on the back of the head (Leontyev, 1975: 59).

The number ten form in Bulgarian is decem, in Polish - dziesięć, in Lithuanian - dešimt and in Latvian - desmit.

As for the number eleven, it is connected with its interpretation by St. Augustine, who associated it with sin, believing that this number represents a perfection of "ten" with a redundant "one". Therefore, eleven is a number that symbolized, first of all, danger, conflict, mutiny. It was called along with the number 13 "baker's / devil's dozen" (Dictionary of Symbols). It is noteworthy that on September 11, 2001, the terrorist attack was carried out in the USA.

The etymology of the number eleven goes back to the phraseological fusion which denotes one in excess of ten (Shanskiy, Ivanov, Shanskaya, 1975: 304), in Bulgarian it is eдuнadecem, in Polish jedenaście. In the Baltic languages, the form of this number is derived in Lithuanian from vienas vienuolika and in Latvian - from viēns - vienpadsmit.

The number twelve is considered a lucky number, a symbol of wealth, perfection. This was facilitated by the fact that this number arose from the multiplication of three and four. The number twelve belongs to the most sacred in the mythological cultures numerical patterns: twelve months of the year, respectively, and twelve signs of the Zodiac (six male and six female). 
The etymology of the number twelve is of Eastern Slavic nature, denoting two over ten (Shanskiy, Ivanov, Shanskaya, 1975: 120): in Bulgarian it is двaнadecem, in Polish -dwanaście. In the Baltic languages the form of this number is derived in Lithuanian from $d u-d v y l i k a$ and in Latvian from divi-divpadsmit.

But the number thirteen is unfortunate, because it follows the happy twelve. As a rule, it was used in fortune-telling and witchcraft ("baker's dozen"). Ancient Jews represented this number by the letter " $\mathrm{M}$ ", and the first letter of the Hebrew word for "death" was this letter. Such a coincidence was not accidental, since the Jews had a belief that if thirteen people come together, it warps misfortune and even death.

In the Christian religion, the thirteen superstition is associated with such a circumstance: according to the Gospel narrative, Jesus Christ had twelve disciples. During the Last Supper, which/ together with Jesus, was attended by thirteen people, one of his disciples, Judas Iscariot, who was in charge of the treasury, betrayed Christ for 30 silver coins.

The form of the number thirteen is mpuнadecem in Bulgarian, trynaście in Polish, trylika in Lithuanian, trīspadsmit in Latvian.

\section{Conclusions}

Summarizing the issue of the necessity to compile a passport for every number and its symbolic sacralization in different cultures, we note that the primary initial criterion for systematizing such a passport-calendar (data bank) should be numerical symbolism reflected in myths of different nations. It helps to reveal the internal properties and qualities of various events through quantitative characteristics. Along with qualitative properties, all objects also have quantitative measurements, like magnitude, volume, pace of the processes, as well as a number by which, starting from the mythological thinking of a person, objects and phenomena were counted.

Considering the process of symbolization of numbers from one to thirteen in the mythopoetic traditions of different cultures, it becomes obvious that their paradigmatics (composition and properties of the members of the numerical series), and syntagmatics (participation of the numbers in texts and, above all, sacred) were essential (Toporov, 1998: 631).

The perspectives of further research in the field is the study of aspects in the civilizational dynamics of numbers, taking into account their national and cultural motivation, contextuality, and situationality.

\section{References}

Aristotle. (1975). Metaphysics. Aristotle. Essays: in 4 Vol. Moscow: Mysl, Vol. 1.

Borodin, A. I. (1975). Number and Mysticism. Donetsk: Donbass.

Chelyshev, P. V. (2017). The Numerical Symbolism of Ancient Mythology on the Example of the Epic Poems of Hesiod and Homer. Istoricheskiye. filosofskiye. politicheskiye i yuridicheskiye nauki. kulturologiya i iskusstvovedeniye. Voprosy teorii i praktiki, 4(78), 213-216. Tambov: Gramota.

Cirlot, J. E. (1994). A Dictionary of Symbols. Moscow: Refl-book.

Dictionary of the Russian Language: in 4 Vol. (1982). Moscow: Russkiy yazyk. Vol. 2.

Dictionary of the Ukrainian Language: in 11 Vol. (1978). Kyiv: Naukova dumka, Vol. 9. 
Ershov, P. P. (1987). The Little Humpbacked Horse: Russian folk tale in three parts. Kyiv: Radianska shkola, 1987.

Ivanov, V., \& Toporov, V. N. (1965). Slavic Language Modeling Semiotic Systems. (Ancient Period). Moscow: Nauka.

Karulis, K. (1992). Latviešu etimoloǵijas vārdnīca. I. Rīga: Avots.

Korolyov, I. (2020). Discursive Practices as Sign Constructs of Communicative Consciousness. Logos, $102,61-69$.

Large Explanatory Dictionary of the Modern Ukrainian Language (2001). V. T. Busel (ed.). Kyiv; Irpin: VTF "Perun".

Leontyev, A. A. (1975). Paradise for linguists. Znaniye - sila, 5, 58-59.

Lotman, Yu. M. (2001). Semiosphere. Sankt-Petersburg: Iskusstvo-SPB.

Makovskiy, M. M. (1996). Comparative Dictionary of Mythological Symbolism in Indo-European Languages. Moscow: VLADOS.

Native Americans' Arithmetic (1965). Nauka i religiya, 11, 97.

Pakholok, Z. (2019). Ontology of the Category of Repetition as a Psychophysiological Factor. Logos, 100, 104-113.

Propp, V. Ya. (1946). The Historical Roots of s Fairy Tale. Leningrad.: Izd-vo LGU.

Propp, V. Ya. (1963). Folklore and Reality. Russkaya Literatura, 3, 62-84.

Shanskiy, N. M., Ivanov, V. V., \& Shanskaya, T. M. (1975). Short Etymological Dictionary of the Russian Language. Moscow: Prosveshcheniye.

Shichzhan, Ya. (2001). The Number Model as a Fragment of the Russian Language Picture of the World. Moscow: Kompaniya Sputnik.

Spengler, O. (1993). Sunset of Europe. Essays on the morphology of world history: in 2 Vol. Moscow: Mysl. Vol.1. Gestalt and validit.

Taranets, V. H. (1999). The Origin of the Concept of Number and its Language Implementation (to the Origins of Indo-European Proto-Language). Odesa: Astroprynt.

Toporov, V. N. (1998). Numbers. Mify narodov mira. Entsiklopediya: V 2-kh t. / Gl. red. S. A. Tokarev. Moscow: NI “Bolshaya Rossiyskaya entsiklopediya”, T. 2., 629-631.

Tresidder, J. (ed.) (n.d.). A Dictionary of Symbols. Biblioteka Gumer - kulturologiya. Available from: http://www.gumer.info/bibliotek Buks/Culture/JekTresidder.

Vasko, R. (2019). Semiotic and Culturological Passportization of Numeric Phraseosymbols. Logos, 98, 94-103.

Vinogradov, V. A. (1990). Number. Lingvisticheskiy entsiklopedicheskiy slovar. Moscow: Sovetskaya entsiklopediya, 583-584.

Voitovych, V. M. (2002). Ukrainian mythology. Kyiv: Lybid. 